\title{
KREATIVITAS DALAM DESAIN KAIN TENUN PANAWUAN GARUT
}

\section{CREATIVITY IN THE DESIGN OF WOVEN CLOTHS OF PANAWUAN- GARUT}

\author{
Wine Regyandhea Putri ${ }^{1}$, R. Arief Dewanto ${ }^{2}$ \\ ${ }^{1}$ Dosen Politeknik STTT Bandung, 40272, Indonesia \\ 2Dosen Politeknik STTT Bandung, 40272, Indonesia \\ E-mail: reyandheawine@yahoo.com,dewanto89@gmail.com
}

\begin{abstract}
ABSTRAK
Kreativitas merupakan kemampuan untuk menghasilkan sesuatu yang baru. Salah satu produk kreatif yang ada di Kabupaten Garut adalah kain tenun Panawuan dengan berbagai bentuk dan aneka motif yang diterapkan. Motif kain tenun tidak terlepas dari unsur-unsur yang menjadi pendukung terjadinya bentuk-bentuk visual seperti garis, bidang, tekstur dan warna. Oleh karena itu masalah yang dikaji dalam penelitian ini adalah belum adanya pemaparan mengenai wujud motif kain tenun yang mempunyai karakteristik tertentu ditinjau dengan pendekatan estetik dan belum adanya pemaparan mengenai wujud visual yang terdapat pada produk tenun berkorelasi dengan prinsip kreativitas. Metode penelitian yang digunakan adalah metoda kualitatif. Teknik pengumpulan data dalam penelitian ini antara lain: wawancara, observasi dan pencatatan dokumen. Hasil penelitian menunjukan bahwa wujud visual yang banyak terdapat pada produk tenun dilihat dari bentuk motifnya merupakan bentuk geometris dengan warna-warna yang tidak mencolok serta kreativitas dalam produk kain tenun Panawuan merupakan kemampuan menghasilkan sesuatu yang baru, berupa gagasan maupun karya nyata, baik dalam bentuk karya baru maupun kombinasi dari hal-hal yang sudah ada serta mengandung aspek-aspek seperti fluency (kelancaran), flexibility (keluwesan), elaboration (elaborasi) dan originality (keaslian).
\end{abstract}

Kata kunci: estetik morfologi, kreativitas, tenun Panawuan, unsur visual

\begin{abstract}
Creativity is the ability to produce something new. One of the creative products in Garut Regency is Panawuan woven fabric with various forms and motifs applied in the woven fabric. Woven fabric motifs can't be separated from the elements that support the occurrence of visual forms such as lines, fields, textures and colors. Therefore the problem examined in this study is the lack of exposure to the form of woven fabric motifs that have certain characteristics viewed with an aesthetic approach and the lack of exposure to the visual form contained in weaving products correlates with the principle of creativity. The research method in this study is a qualitative research method. Data collection techniques in this study include: interviews, observation and recording of documents. The results showed that many
\end{abstract}


visual forms found in weaving products were seen from their motifs as geometric shapes with inconspicuous colors and creativity in the products of Panawuan woven fabric, which was the ability to produce something new, in the form of real ideas or works, both in the form of new works or a combination of things that already exist and contain aspects such as fluency, flexibility, elaboration and originality.

Keywords: aesthetic morphology, creativity, Panawuan woven, visual element.

\section{PENDAHULUAN}

Suatu produk atau suatu karya dapat dikatakan kreatif jika merupakan suatu ciptaan yang baru atau orisinil dan bermakna dari individu atau bagi lingkungannya. Produk baru dapat disebut karya kreatif jika mendapatkan pengakuan

(penghargaan) oleh masyarakat pada waktu tertentu. Definisi pada dimensi produk merupakan upaya mendefinisikan kreativitas yang berfokus pada produk atau apa yang dihasilkan oleh individu baik sesuatu yang baru/original atau sebuah elaborasi/penggabungan yang inovatif. "Creativity is the ability to bring something new into existence" (Baron, 1976 dalam Reni Akbar-Hawadi dkk, 2001). Definisi yang berfokus pada produk kreatif menekankan pada orisinalitas seperti yang dikemukakan oleh Baron (1969) yang menyatakan bahwa kreativitas adalah kemampuan untuk menghasilkan atau menciptakan sesuatu yang baru. Begitu pula menurut Haefele (1962) dalam Munandar, 1999, yang menyatakan kreativitas adalah kemampuan untuk membuat kombinasi-kombinasi baru yang mempunyai makna sosial. Menurut dua definisi ini maka kreativitas tidak hanya membuat sesuatu yang baru tetapi mungkin saja kombinasi dari sesuatu yang sudah ada sebelumnya.

Salah satu produk kreatif yang ada di Kabupaten Garut adalah kain tenun Panawuan-Garut. Panawuan merupakan daerah penghasil kain tenun di Kabupaten Garut dengan berbagai bentuk dan aneka motif yang diterapkan. Membahas mengenai keberadaan dan perkembangan tenun Panawuan-Garut, tidak terlepas dari lingkungan dan kondisi masyarakat di Panawuan. Pada awalnya masyarakat di Panawuan berprofesi sebagai petani. Adapun tenun yang ada di Panawuan hanyalah tenun putihan saja, yang biasanya digunakan untuk bahan dasar pembuatan batik dan 
tenun yang dibuat sangat minim variasinya sehingga harga jualnya rendah. Seiring dengan perkembangan tenun di Panawuan, pada saat ini sebagian besar masyarakat di Panawuan berpofesi sebagai pengrajin tenun. Hal ini dikarenakan terbentuknya motif khas dan corak yang berwarna pada kain tenun, bahkan menjadi sandaran utama penghidupan masyarakat Panawuan.

Hal ini tidak bisa terlepas dari peran desainer dalam pembuatan motif kain tenun, desainer memiliki peran dalam pembuatan motif kain tenun dan membantu mewujudkan keinginan, cita-cita dan hasrat yang menjadi kebutuhan manusia sesuai dengan keadaan lingkungan sekitar dengan tetap memperlihatkan unsur desain dan prinsip-prinsip desain.

Motif kain tenun hadir di tengah-tengah kehidupan masyarakat sebagai media ungkapan perasaan yang diwujudkan dalam bentuk visual, yang proses penciptaanya tidak lepas dari pengaruh-pengaruh lingkungan, ditunjukkan sebagai pelengkap rasa estetik dan bentuknya memiliki makna simbolik. Motif kain tenun tidak terlepas dari unsur-unsur yang menjadi pendukung terjadinya bentuk-bentuk visual seperti garis, bidang, tekstur dan warna.

Produk tenun, sebagai bagian dari produk tekstil yang berkembang di beberapa wilayah Indonesia, dapat diasumsikan bahwa dasar perancangan dan wujud visual motif tenun yang dihasilkan merupakan pengejawantahan nilai-nilai luhur dan tradisi masyarakat setempat yang syarat dengan muatan aspirasi lokal. Hal ini berlaku pada hasil karya dari pelaku seni khususnya pengrajin tenun di Panawuan Garut, karena dalam penciptaannya senantiasa dipedomani oleh kebudayaan. Oleh karena itu kain tenun Panawuan selain mengandung nilai-nilai estetik, juga dapat merefleksikan nilai-nilai sosial budaya yang ada.

Visualisasi dari motif kain tenun ditinjau dari pendekatan estetik mempunyai keindahan yang tercermin dalam komposisi bentuk dan warna yang tersusun secara harmonis dan dinamis. Kemajuan kreativitas dalam produk kain tenun dan kesinambungan dari nilai estetik motif kain tenun Panawuan-Garut yang terjadi bukan berarti berhenti begitu saja, sehingga penelitian ini perlu dilakukan karena 
perlu adanya penggalian yang lebih dalam terhadap kreativitas produk melalui bentuk-bentuk motif kain tenun Panawuan-Garut, guna memperkaya khasanah kebudayaan Nasional, khususnya di bidang seni motif kain tenun Panawuan-Garut. Usaha-usaha tersebut perlu dilakukan oleh semua pihak, baik oleh praktisi desain, pemerintah, maupun pihak-pihak lain yang terkait.

Berdasarkan uraian masalah tersebut di atas, rumusan masalah yang dapat dikemukakan adalah:

a. Belum adanya pemaparan mengenai wujud motif kain tenun Panawuan-Garut yang mempunyai karakteristik tertentu ditinjau dengan pendekatan morfologi estetik.

b. Belum adanya pemaparan mengenai wujud visual yang terdapat pada produk tenun Panawuan- Garut berkorelasi dengan prinsip kreativitas.

Tujuan dari penelitian ini adalah mendeskripsikan wujud visual motif kain tenun Panawuan-Garut ditinjau dari pendekatan morfologi estetik serta membuat formulasi kreativitas dalam produk kain tenun Panawuan-Garut, sedangkan manfaat yang didapatkan dari hasil penelitian ini adalah data dan simpulan hasil analisis yang dapat dimanfaatkan sebagai material dalam penelitian yang dilakukan oleh peneliti dari bidang yang sama dan dengan mengetahui wujud visual motif kain tenun kampung Panawuan-Garut yang ditinjau dari pendekatan estetik maka dapat mengetahui keselarasan antara kualitas visual dengan prinsip kreativitas pada produk tenun Panawuan-Garut. Penelitian ini memfokuskan pada kreativitas dalam produk kain tenun Panawuan-Garut dan perkembangannya ditinjau dari kualitas visual dan prinsip kreativitas pada produk kain tenun PanawuanGarut.

\section{METODA PENELITIAN}

Metode penelitian yang digunakan adalah metode kualitatif. Model kajian desain dalam penelitian menggunakan model kajian estetik dengan metode deskriptif-kualitatif. Data-data yang digunakan dalam penelitian ini merupakan data-data visual pada produk tenun yang dianalisis dengan menggunakan teori estetik morfologi, dimana teori ini berperan dalam mengenali jenis-jenis bentuk, dengan 
mengenali segi elemen, detail, bagian, material, imaji, ide dan apapun yang termasuk di dalamnya (Munro, 1970). Pada penelitian ini, dipergunakan metodologi deskriptif kualitatif yang bertujuan untuk memperoleh gambaran menyeluruh dari seluruh obyek penelitian. Penelitian dengan metode deskriptif, dibuat laporan secara sistematis dan faktual mengenai kenyataan di lapangan serta sifat dari fenomena obyek penelitian. Data primer pada penelitian ini berupa bahan visual kain tenun Panawuan yang merupakan hasil dokumentasi perajin.

Teknik pengumpulan data merupakan hal yang sangat penting untuk memperoleh kejelasan dan kerincian data yang digunakan. Teknik pengumpulan data juga merupakan prosedur yang sistematis dan standar untuk memperoleh data yang diperlukan. Pengumpulan data dalam penelitian kualitatif dilakukan pada kondisi yang alamiah, sumber data primer dan teknik pengumpulan data lebih banyak pada observasi berperan serta, wawancara dan dokumentasi. Adapun teknik pengumpulan data dalam penelitian ini adalah sebagai berikut: Pertama; Wawancara, yaitu suatu cara teknik pengumpulan data dengan bertanya langsung kepada informan yang bersangkutan guna memperoleh informasi dan keterangan untuk tujuan penelitian. Responden yang menjadi informan adalah para perajin, desainer, sesepuh (tokoh masyarakat) yang dipilih berdasarkan pertimbangan

pengetahuan, pengalaman, dan wawasan yang berkaitan dengan kajian penelitian dan permasalahan tenun. Kedua; Observasi, yaitu dengan melakukan pengamatan langsung dan sistematis terhadap obyek penelitian untuk mendapatkan informasi atau data yang disampaikan informan secara lisan sesuai pokok penelitian. Pengumpulan data melalui observasi langsung dilakukan untuk mengamati secara langsung perkembangan motif dan produk kain tenun. Ketiga; Dokumentasi, yaitu teknik yang digunakan untuk melengkapi data yang diperoleh dari hasil wawancara dan observasi supaya data yang diperlukan dapat dipertanggung jawabkan validitasnya. Dokumentasi yang diambil dan dijadikan bahan kajian dalam penelitian ini adalah fotofoto motif kain tenun Panawuan-Garut. Dokumentasi digunakan juga untuk 
menggali data sekunder untuk memperoleh informasi yang memadai dari berbagai literature agar mendapatkan kedalaman dan keshahihan materi dari permasalahan penelitian. Data-data yang diperoleh berupa foto-foto, hasil wawancara, hasil studi pustaka akan dicatat dan dianalisis untuk menghasilkan kesimpulan dan laporan penelitian.

Adapun tahapan penelitian ini adalah :

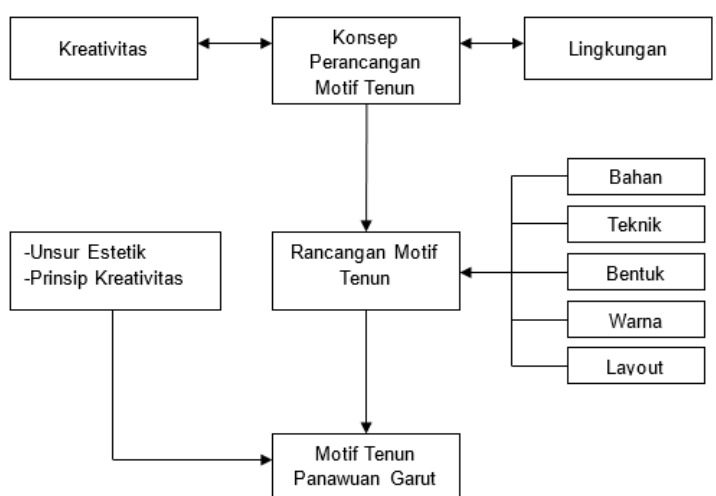

Gambar 2.1. Kerangka Penelitian

(Putri, 2019)

\section{HASIL DAN PEMBAHASAN}

\subsection{Penelitian Terdahulu}

Kajian literatur dari hasil penelitian sebelumnya dilakukan oleh peneliti agar dapat memahami dan mempertimbangkan parameter yang akan digunakan dalam penelitian ini. Fokus dan metoda penelitian sebelumnya serta korelasi dan perbedaan dengan penelitian yang akan dilakukan disajikan pada Tabel 3.1 .

Tabel 3.1 Penelitian Terdahulu

\begin{tabular}{|c|c|c|c|}
\hline No. & $\begin{array}{l}\text { Peneliti \& judul } \\
\text { penelitian }\end{array}$ & & $\begin{array}{l}\text { rbedaan } \\
\text { an yang } \\
\text { kan }\end{array}$ \\
\hline 1. & 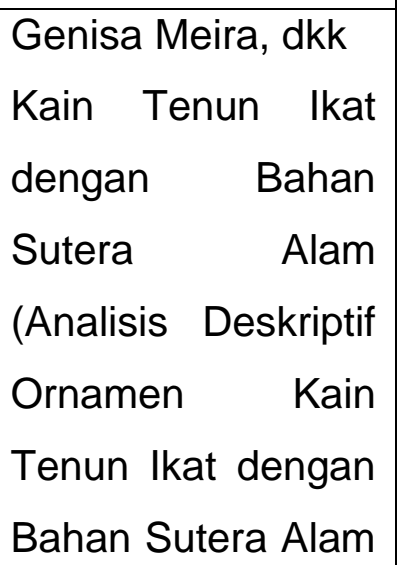 & $\begin{array}{l}\text { Analisis } \\
\text { Oranamen Kain Tenun lkat } \\
\text { dengan Bahan Sutera } \\
\text { Alam di Kampung Tenun } \\
\text { Panawuan Kabupaten } \\
\text { Garut. Metode penelitian } \\
\text { yang digunakan adalah } \\
\text { metode deskriptif analisis }\end{array}$ & $\begin{array}{l}\text { Objek penelitian dan } \\
\text { penelitian yang akan } \\
\text { dilakukan yaitu mengenai } \\
\text { produk tenun yang ada di } \\
\text { kampung tenun Panawuan } \\
\text { Garut. Penelitian yang akan } \\
\text { dilakukan adalah penelitian } \\
\text { mengenai kreativitas dalam }\end{array}$ \\
\hline
\end{tabular}




\begin{tabular}{|c|c|c|c|}
\hline & $\begin{array}{l}\text { di Kampung Tenun } \\
\text { Panawuan } \\
\text { Kabupaten Garut } \\
2013\end{array}$ & $\begin{array}{l}\text { dengan pendekatan } \\
\text { kualitatif }\end{array}$ & $\begin{array}{l}\text { desain kain tenun kampung } \\
\text { tenun Panawuan Garut. } \\
\text { Metode penelitian yang } \\
\text { digunakan yaitu pendekatan } \\
\text { kualitatif yang dianalisis } \\
\text { menggunakan morfologi } \\
\text { estetik untuk menghasilkan } \\
\text { data deskriptif berupa } \\
\text { pemaparan mengenai } \\
\text { kreativitas dalam desain } \\
\text { kain tenun } \\
\text { yang dalam hal ini melihat } \\
\text { korelasi antara wujud visual } \\
\text { dan prinsip kreativitas } \\
\begin{array}{l}\text { sehingga mempengaruhi } \\
\text { kreativitas }\end{array} \\
\begin{array}{l}\text { pembuatan kain } \\
\text { Panawuan garut }\end{array}\end{array}$ \\
\hline 2. & $\begin{array}{l}\text { Achmad Ibrahim } \\
\text { Makki, dkk } \\
\text { Pengembangan } \\
\text { Desain Motif Kain } \\
\text { Tenun Ikat Garut } \\
\text { Berdasarkan } \\
\text { Indonesia Trend } \\
\text { Forecasting } \\
2017\end{array}$ & $\begin{array}{l}\text { Alternatif desain } r \text { kain } \\
\text { tenun ikat yang sesuai } \\
\text { dengan Indoneisa trend } \\
\text { forecasting 2016-2017 dan } \\
\text { kearifan lokal Garut, } \\
\text { Metodologi yang } \\
\text { digunakan adalah study } \\
\text { pustaka untuk menentukan } \\
\text { sumber ide desain dan } \\
\text { sumber ide warna serta } \\
\text { eksperimen untuk } \\
\text { merealisasikan desain } \\
\text { dalam bentuk kain tenun } \\
\text { ikat. }\end{array}$ & \\
\hline
\end{tabular}




\subsection{Tenun Panawuan Garut}

Panawuan merupakan daerah penghasil tenun yang ada di Garut. Menurut ketua Paguyuban Kampung Tenun Panawuan Garut, Hendar Rogesta, dahulu mayoritas penduduk Kampung Panawuan berprofesi sebagai petani, akan tetapi saat ini sebagian besar penduduk Kampung Panawuan berprofesi sebagai perajin tenun Para "mantan" petani menjadikan kerajinan tenun sebagai sumber penghasilan utama karena pendapatan dari usaha tersebut jauh lebih baik. Saat ini ada 16 kelompok tenun yang melibatkan 150 warga tumbuh di Panawuan. Produk yang dihasilkan di antaranya tenun ikat, tenun bulu, tenun sulam dan tenun sulam kombinasi batik tulis.

Secara umum, proses pertenunan memiliki prinsip-prinsip yang sama, dimana yang membedakan hanyalah jenis peralatan/mesin tenun yang digunakan, serta perbedaan teknik pembentukan motif yang dipilih. Proses pertenunan cukup panjang dan rumit, dimulai sejak proses perancangan, persiapan, hingga pertenunan itu sendiri. Proses persiapan pertenunan merupakan proses yang mencakup beberapa tahapan yang sangat penting agar dapat menghasilkan produk akhir kain dengan kekuatan dan kerapihan sesuai standar yang berlaku.

Urutan proses pertenunan di kampung tenun Panawuan Garut secara garis besar terdiri dari:

\section{a. Proses Perancangan}

- Pembuatan sketsa desain, perancangan kain tenun dilakukan melalui sketsa gambar diatas kertas, pada tahap ini desainer atau perajin dapat merancang jenis dan bentuk motif, paduan warna, dan bentuk kain tenun secara visual.

- Pembuatan rencana tenun, untuk bisa menentukan kebutuhan benang lusi dan pakan, konstruksi kain, jenis teknik pembentuk motif yang dibutukan, sketsa desain harus diterjemahkan ke dalam sebuah rencana tenun. Rencana tenun meliputi jenis dan nomor benang, warna benang lusi, tetal lusi, nomor sisir, susunan cucukan sisir, total benang lusi, lebar sisir efektif, panjang hani, dan susunan benang lusi pada beam. 
- Perhitungan kebutuhan benang, perhitungan kebutuhan benang lusi dan pakan diperoleh saat membuat rencana tenun. Perhitungan ini berguna untuk proses penyusunan benang lusi, dengan demikian akan mengeliminasi kemungkinan kesalahan ukuran pada susunan lusi pada beam.

- Penyusunan kartu motif, selain perancangan desain kain tenun secara visual, harus dibuat pula susunan kartu motif sebagaimana desain yang diinginkan. Motif bisa berupa motif dobby atau motif jacquard. Susunan media pembentuk motif inilah yang harus diterjemahkan secara terperinci di dalam rencana tenun.

\section{b. Proses Persiapan Benang}

- Persiapan benang lusi (warp), benang lusi merupakan benang yang menjadi dasar struktur kain, oleh sebab itu penanganan benang lusi dilakukan secara hati-hati dan harus sesuai dengan standar sehingga hasil tenun yang diperoleh kualitasnya baik. Proses persiapan benang lusi di kampung tenun
Panawuan diantaranya proses pengelosan benang, proses penghanian, proses pengkanjian, proses pencucukan dan proses pengikatan.

- Persiapan benang pakan (weft), benang pakan merupakan benang yang posisinya $90^{\circ}$ dengan benang lusi, dan diluncurkan kearah lebar kain dengan bantuan peluncur seperti teropong. Benang pakan bisa juga disebut sebagai benang pengisi struktur kain, beragam jenis benang dapat digunakan secara langsung tanpa penanganan khusus sebelumnya. Proses penggulungan benang pakan dalam bentuk palet biasa disebut dengan proses pemaletan.

c. Proses Pertenunan, dilakukan dengan melakukan gerakan utama yang terdiri dari pembukaan mulut lusi, peluncuran benang pakan dan pengetekan. Pada proses ini di Panawuan menggunakan Alat Tenun Bukan Mesin (ATBM) sehingga proses tenun bergantung pada kemampuan pengrajin untuk dapat merealisasikan produk 
sesuai dengan desain yang dirancang

d. Proses Finishing, pada proses ini dilakukan proses pelipatan pada kain tenun.

\subsection{Prinsip Kreativitas pada Tenun Panawuan Garut}

Menurut Sunarya, kreativitas merupakan ujung tombak desain, tidak bisa dilepaskan dari dunia gagas manusia, yaitu: unsur akal (rasio, logika, pikiran, ide, dst.) dan unsur rasa (kreativitas, intuisi, ilham, selera, nilai-nilai, dst.). Kreativitas (berpikir kreatif atau berpikir divergen) adalah kemampuan berkreasi berdasarkan data atau informasi yang tersedia dalam menemukan banyak kemungkinan jawaban terhadap suatu masalah, dimana penekanannya adalah pada kuantitas, ketepatgunaan, dan keragaman jawaban. Jawaban - jawaban yang diberikan harus sesuai dengan masalah yang dihadapi dengan memperhatikan kualitas dan mutu dari jawaban tersebut. Berpikir kreatif dalam menjawab segala masalah adalah dengan menunjukkan kelancaran berpikir (dapat memberikan banyak jawaban), menunjukkan keluwesan dalam berpikir (fleksibilitas), memberikan jawaban yang bervariasi, dan melihat suatu masalah dari berbagai sudut tinjauan. Secara operasional kreativitas dapat dirumuskan sebagai "kemampuan yang mencerminkan kelancaran, keluwesan (fleksibilitas), dan orisinalias dalam berpikir, serta kemampuan untuk mengelaborasi (mengembangkan, memperkaya, memperinci) suatu gagasan. Kreativitas sebagai proses berpikir yang membawa seseorang berusaha menemukan metode dan cara baru di dalam memecahkan suatu masalah. Kemudian ia menemukan bahwa kreativitas yang penting bukan apa yang dihasilkan dari proses tersebut tetapi yang pokok adalah kesenangan dan keasyikan yang terlihat dalam melakukan aktivitas kreatif. Berdasarkan uraian sebelumnya dapat disimpulkan bahwa kreativitas merupakan suatu proses berpikir yang lancar, lentur dan orisinal dalam menciptakan suatu gagasan yang bersifat unik, berbeda, orisinal, baru, indah, efisien, dan bermakna, serta membawa seseorang berusaha menemukan metode dan cara baru di dalam memecahkan suatu masalah. 
Begitu pula dengan kain tenun yang dihasikan di kampung tenun Panawuan Garut. Berdasarkan data kain tenun Panawuan Garut yang didapat, maka dapat dilihat adanya kreativitas dalam pembuatan kain tenun Panawuan Garut yang berawal dari pembuatan tenun ikat kemudian mengkreasikannya menjadi tenun bulu, tenun sulam dan yang terakhir adalah tenun sulam kombinasi batik. Pendekatan secara estetik untuk kain tenun Panawuan Garut pada penelitian ini dapat dilakukan dengan menggunakan identifikasi unsur rupa sebagai wujud visual yang terdapat pada kain tenun Panawuan Garut. Pendekatan estetik morfologi digunakan dalam pembedahan unsurunsur visual pada kain tenun Panawuan Garut, seperti pola, bangun dasar, elemen-elemen, outline, isi dan warna. Analisis morfologi pada penelitian ini berperan dalam menganalisis dan mengidentifikasi kain tenun Panawuan Garut dengan tujuan menunjukan adanya hubungan tertentu antara jenis-jenis bentuk visual dan produk tenun yang dihasilkan. Data-data kain tenun Panawuan Garut kemudian dianalisis sehingga ditemukan deskripsi bentuk-bentuk dari kain tenun Panawuan Garut serta akan dibahas pula korelasi antara prinsip kreativitas dan wujud visual pada produk kain tenun Panawuan Garut. prinsip-prinsip kreativitas yang akan dibahas diantaranya fluency yang terdapat pada produk tenun, flexibility dalam produk tenun, elaboration pada produk tenun, serta originality yang terkandung pada produk tenun.

\subsection{Analisis Visual Kain Tenun Panawuan Garut}

Analisis visual kain tenun Panawuan Garut bertujuan untuk menunjukan adanya hubungan tertentu antara estetik morfologi dan kain tenun Panawuan Garut. Relasi yang terjadi di antaranya memunculkan unsur-unsur visual dasar yang didapat dari pendekatan estetik yaitu titik, garis, bidang dan warna. Titik merupakan unsur visual yang paling sederhana, tidak memiliki ukuran atau dimensi. Elemen titik merupakan sebuah permulaan dari penyusunan elemen lain terutama elemen garis yang tersusun atas titik-titik dengan suatu tujuan tertentu. Titik merupakan tempat awal pada proses pembuatan garis dalam analisis kain tenun Panawuan Garut. 
Unsur garis merupakan unsur dari proses awal pembuatan tenun serta unsur utama dalam pembentukan motif. Proses awal dalam pembentukan motif adalah pembuatan garis-garis yang digunakan pada saat proses pembuatan motif. Unsur garis pada kain tenun Panawuan banyak terdapat pada motif yang dihasilkan seperti zig-zag atau belah ketupat.

e. Unsur berikutnya adalah bidang, bidang terjadi atas pertemuan garis yang berbatas, oleh karena itu variasi pembatasan garis dapat memunculkan bidang baik itu geometris maupun non geometris. Dalam tenun khususnya dalam pembuatan motif selain banyak menggunakan bentuk geometris juga banyak menstilasi bentukbentuk alam baik flora maupun fauna. Unsur selanjutnya adalah warna, unsur warna merupakan unsur yang sangat penting, unsur warna dapat memperindah suatu produk yang dihasilkan. Analisis terhadap motif kain tenun Panawuan Garut disajikan pada Tabel 3.2.

Tabel 3.2 Analisis pada Kain Tenun Panawuan Garut

\begin{tabular}{|c|c|c|c|c|}
\hline $\begin{array}{c}\text { Elemen } \\
\text { Visual } \\
\text { Tenun } \\
\text { Panawuan }\end{array}$ & Tenun Ikat & Tenun Bulu & Tenun Sulam & $\begin{array}{c}\text { Tenun Sulam } \\
\text { Kombinasi } \\
\text { Batik }\end{array}$ \\
\hline $\begin{array}{l}\text { Pola/ } \\
\text { Layout }\end{array}$ & Satu bata & Satu bata & Satu bata & Satu bata \\
\hline $\begin{array}{l}\text { Bangun } \\
\text { dasar }\end{array}$ & $\begin{array}{l}\text { - Non } \\
\text { geometris } \\
\text { (motif bunga } \\
\text { dan etnik) } \\
\text { - Geometris } \\
\text { (motif belah } \\
\text { ketupat/waji } \\
\text { k) }\end{array}$ & $\begin{array}{l}\text { - Geometris } \\
\text { (motif belah } \\
\text { ketupat/wajik } \\
\text {, segitiga siku- } \\
\text { siku, zig-zag, } \\
\text { jajar genjang, } \\
\text { dan bangun } \\
\text { segi enam) }\end{array}$ & $\begin{array}{l}\text { - Geometris } \\
\text { (motif jajar } \\
\text { genjang, } \\
\text { belah } \\
\text { ketupat/wajik } \\
\text {, dan zig-zag) }\end{array}$ & $\begin{array}{l}\text { - Non } \\
\text { geometris } \\
\text { (motif bunga) } \\
\text { - Geometris } \\
\text { (motif belah } \\
\text { ketupat/wajik } \\
\text {, zig-zag, dan } \\
\text { jajar genjang) }\end{array}$ \\
\hline Elemen & $\begin{array}{l}\text { Garis lurus, } \\
\text { garis } \\
\text { lengkung }\end{array}$ & Garis lurus & Garis lurus & $\begin{array}{ll}\text { Titik, garis lurus } \\
\text { dan garis } \\
\text { lengkung }\end{array}$ \\
\hline
\end{tabular}




\begin{tabular}{|c|c|c|c|c|}
\hline $\begin{array}{c}\text { Elemen } \\
\text { Visual } \\
\text { Tenun } \\
\text { Panawuan }\end{array}$ & Tenun Ikat & Tenun Bulu & Tenun Sulam & $\begin{array}{c}\text { Tenun Sulam } \\
\text { Kombinasi } \\
\text { Batik }\end{array}$ \\
\hline Tekstur & $\begin{array}{l}\text { Tenun } \\
\text { dengan } \\
\text { anyaman } \\
\text { polos, } \\
\text { permukaan- } \\
\text { nya datar. }\end{array}$ & $\begin{array}{l}\text { Tenun bulu, } \\
\text { permukaannya } \\
\text { timbul karena } \\
\text { efek bulu yang } \\
\text { ditimbulkan. }\end{array}$ & $\begin{array}{l}\text { Tenun sulam, } \\
\text { permukaannya } \\
\text { timbul karena } \\
\text { efek sulam } \\
\text { pada kain. }\end{array}$ & $\begin{array}{l}\text { Tenun sulam } \\
\text { kombinasi } \\
\text { batik, } \\
\text { permukaannya } \\
\text { timbul karena } \\
\text { efek sulam. }\end{array}$ \\
\hline Warna & $\begin{array}{l}\text { Terdiri dari } \\
\text { beberapa } \\
\text { warna di } \\
\text { antaranya } \\
\text { biru, merah, } \\
\text { kuning, hijau } \\
\text { dan putih. }\end{array}$ & $\begin{array}{l}\text { Terdiri dari dua } \\
\text { warna utama } \\
\text { seperti merah } \\
\text { dan putih, putih } \\
\text { dan orange, } \\
\text { putih dan } \\
\text { coklat, biru tua } \\
\text { dan biru muda. }\end{array}$ & $\begin{array}{l}\text { Terdiri dari } \\
\text { beberapa } \\
\text { warna } \\
\text { diantaranya } \\
\text { biru, merah, } \\
\text { kuning, coklat, } \\
\text { abu, hitam }\end{array}$ & $\begin{array}{l}\text { Terdiri dari } \\
\text { beberapa } \\
\text { warna } \\
\text { diantaranya } \\
\text { merah, kuning, } \\
\text { biru, putih, } \\
\text { hijau, coklat, } \\
\text { hitam }\end{array}$ \\
\hline
\end{tabular}

Tabel 3.2 merupakan analisis pada kain tenun Panawuan Garut, baik itu kin tenun ikat, kain tenun bulu, kain tenun sulam dan kain tenun sulam kombinasi batik. Pada kain tenun ikat Panawuan Garut pola yang digunakan pada setiap motif merupakan pola pengulangan satu bata, bangun dasar yang digunakan pada kain tenun ikat Panawuan Garut merupakan bentuk Pada kain tenun bulu Panawuan Garut pola yang digunakan pada setiap motif merupakan pola pengulangan satu bata, bangun dasar yang digunakan geometris seperti motif belah ketupat dan non geometris seperti motif bunga dan etnik. Elemen yang terdapat pada kain tenun ikat Panawuan Garut merupakan garis lurus dan lengkung. Tekstur tenunan berupa ayaman polos dengan permukaan yang datar. Kain tenun ikat Panawuan Garut terdiri dari beberapa warna di antaranya biru, merah, kuning, hijau dan putih. pada kain tenun bulu Panawuan Garut merupakan bentuk geometris seperti motif belah ketupat, segitiga siku-siku, zig-zag, jajar genjang dan bangun segi 
enam. Elemen yang terdapat pada kain tenun bulu Panawuan Garut merupakan garis lurus. Tekstur permukaan kain tenun bulu timbul karena efek bulu yang dihasilkan pada saat proses pertenunan. Kain tenun bulu Panawuan Garut terdiri dari dua warna utama seperti merah dan putih, putih dan orange, putih dan coklat, biru tua dan biru muda.

Pada kain tenun sulam Panawuan Garut pola yang digunakan pada setiap motif merupakan pola pengulangan satu bata, bangun dasar yang digunakan pada kain tenun sulam Panawuan Garut merupakan bentuk geometris seperti motif belah ketupat, zig-zag, dan jajar genjang. Elemen yang terdapat pada kain tenun sulam Panawuan Garut merupakan garis lurus. Tekstur kain tenun sulam Panawuan Garut permukaan kainnya timbul karena efek sulam yang dihasilkan pada saat proses pertenunan. Kain tenun sulam Panawuan Garut terdiri dari beberapa warna diantaranya biru, merah, kuning, coklat, abu, hitam.

Pada kain tenun sulam kombinasi batik Panawuan Garut pola yang digunakan pada setiap motif merupakan pola pengulangan satu bata, bangun dasar yang digunakan pada kain tenun sulam kombinasi batik Panawuan Garut merupakan bentuk geometris seperti motif belah ketupat, zig-zag, dan jajar genjang dan bentuk non geometris seperti motif bunga. Elemen yang terdapat pada kain tenun sulam kombinasi batik Panawuan Garut merupakan titik, garis lurus, dan garis lengkung. Tekstur kain tenun sulam kombinasi batik Panawuan Garut permukaan kainnya timbul karena efek sulam yang dihasilkan pada saat proses pertenunan. Kain tenun sulam kombinasi batik Panawuan Garut terdiri dari beberapa warna diantaranya merah, kuning, biru, putih, hijau, coklat, hitam.

Motif kain tenun Panawuan dianalisis menggunakan estetik morfologi, di mana yang diteliti adalah bentuk yang dihasilkan pada kain tenun Panawuan. Adapun bentuk yang paling dominan terdapat pada tenun panawuan adalah bentuk wajik dan zig-zag, sedangkan elemen utama pembentuk motif tenun Panawuan yaitu garis lurus dan garis lengkung. Tekstur yang ada pada kain tenun panawuan dihasilkan melalui suatu proses desain tekstil yaitu desain permukaan di mana desain terbentuk setelah kain selesai ditenun. Warna- 
warna yang cenderung digunakan pada tenun Panawuan diantaranya

\subsection{Kreativitas Kain Tenun Panawuan}

Kreativitas pada intinya merupakan kemampuan untuk menghasilkan sesuatu yang baru, baik berupa gagasan maupun karya nyata, baik dalam bentuk karya baru maupun kombinasi dari hal-hal yang sudah ada, yang semuanya itu relatif berbeda dengan apa yang telah ada sebelumnya. Kreativitas memiliki 4 aspek yang utama yaitu fluency (kelancaran), flexibility (keluwesan), elaboration (elaborasi) dan originality (keaslian). Hal tersebut berlaku pada produk kain tenun Panawuan. Fluency (kelancaran) pada tenun Panawuan dikaitkan dengan ide-ide yang dihasilkan pada produk tenun Panawuan. Flexibility (keluwesan) pada tenun Panawuan dikaitkan warna merah, biru, coklat, kuning, hijau dan putih.

dengan varian/ kemungkinan motif yang dihasilkan pada produk tenun Panawuan. Elaboration (elaborasi) pada tenun Panawuan dikaitkan dengan proses peningkatan ide pada pembuatan tenun Panawuan sehingga produk yang dihasilkan cenderung lebih kompleks. Originality (keaslian) pada tenun Panawuan dikatikan dengan keunikan produk yang dibuat. Parameter pengukuran kreativitas yang digunakan dalam penelitian ini adalah melalui pendekatan objektif dimana untuk menilai secara langsung kreativitas suatu produk berupa benda atau karya-karya kreatif lain yang dapat diobservasi wujud fisiknya. Aspek kreativitas pada kain tenun Panawuan Garut disajikan pada Tabel 3.3. 
Tabel 3.3 Aspek Kreativitas pada Kain Tenun Panawuan Garut

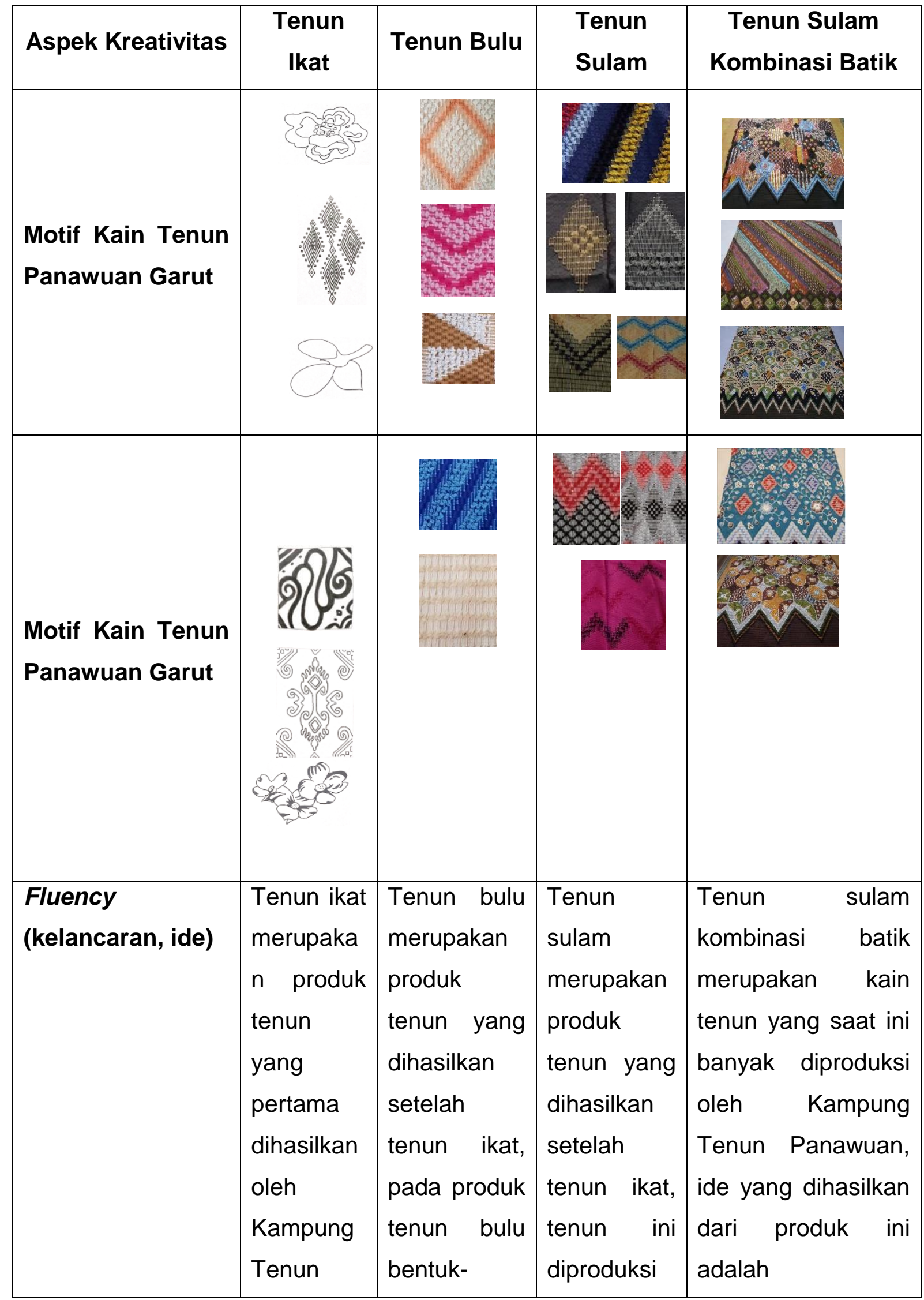




\begin{tabular}{|c|c|c|c|c|}
\hline Aspek Kreativitas & $\begin{array}{c}\text { Tenun } \\
\text { Ikat }\end{array}$ & Tenun Bulu & $\begin{array}{l}\text { Tenun } \\
\text { Sulam }\end{array}$ & $\begin{array}{c}\text { Tenun Sulam } \\
\text { Kombinasi Batik }\end{array}$ \\
\hline & $\begin{array}{l}\text { Panawuan } \\
\text { Garut. } \\
\text { Awalnya } \\
\text { motif- } \\
\text { motif yang } \\
\text { dihasilkan } \\
\text { oleh kain } \\
\text { tenun ikat } \\
\text { Panawuan } \\
\text { Garut } \\
\text { adalah } \\
\text { motif } \\
\text { bunga dan } \\
\text { wajik. }\end{array}$ & $\begin{array}{l}\text { bentuk yang } \\
\text { dihasilkan } \\
\text { merupakan } \\
\text { bentuk } \\
\text { geometris, } \\
\text { dikatakan } \\
\text { tenun bulu } \\
\text { karena pada } \\
\text { permukaan } \\
\text { kain } \\
\text { terdapat } \\
\text { bulu-bulu } \\
\text { yang } \\
\text { dihasilkan } \\
\text { dari proses } \\
\text { penggunting } \\
\text { an benang. }\end{array}$ & $\begin{array}{l}\text { karena } \\
\text { pada saat } \\
\text { itu tenun } \\
\text { ikat dan } \\
\text { tenun bulu } \\
\text { mengalami } \\
\text { penurunan } \\
\text { dalam hasil } \\
\text { penjualan. } \\
\text { Produk ini } \\
\text { dikatakan } \\
\text { tenun } \\
\text { sulam } \\
\text { karena } \\
\text { pada saat } \\
\text { proses } \\
\text { pertenunan } \\
\text { dilakukan } \\
\text { juga proses } \\
\text { penyulama } \\
\mathrm{n} \text { sehingga } \\
\text { menghasilk } \\
\text { an tenun } \\
\text { sulam. }\end{array}$ & $\begin{array}{l}\text { mengkombinasikan } \\
\text { tenun sulam yang } \\
\text { kemudian diberikan } \\
\text { proses pembatikan. } \\
\text { Bentuk yang } \\
\text { dihasilkan dari } \\
\text { produk ini adalah } \\
\text { bentuk geometris } \\
\text { pada } \\
\text { sulamnya dan } \\
\text { bentuk non } \\
\text { geometris pada } \\
\text { motif batiknya. }\end{array}$ \\
\hline $\begin{array}{l}\text { Flexibility } \\
\text { (kemungkin-an } \\
\text { varian) }\end{array}$ & $\begin{array}{l}\text { Motif-motif } \\
\text { pada } \\
\text { tenun ikat } \\
\text { merupaka } \\
\text { n motif } \\
\text { non }\end{array}$ & $\begin{array}{l}\text { Motif-motif } \\
\text { pada tenun } \\
\text { bulu } \\
\text { merupakan } \\
\text { motif } \\
\text { geometris }\end{array}$ & $\begin{array}{l}\text { Motif-motif } \\
\text { pada tenun } \\
\text { sulam } \\
\text { merupakan } \\
\text { motif } \\
\text { geometris }\end{array}$ & $\begin{array}{lr}\text { Motif-motif } & \text { pada } \\
\text { tenun } & \text { sulam } \\
\text { kombinasi } & \text { batik } \\
\text { merupakan } & \\
\text { perpaduan antara } \\
\text { motif geometris dan }\end{array}$ \\
\hline
\end{tabular}




\begin{tabular}{|c|c|c|c|c|}
\hline Aspek Kreativitas & $\begin{array}{l}\text { Tenun } \\
\text { Ikat }\end{array}$ & Tenun Bulu & $\begin{array}{l}\text { Tenun } \\
\text { Sulam }\end{array}$ & $\begin{array}{c}\text { Tenun Sulam } \\
\text { Kombinasi Batik }\end{array}$ \\
\hline & $\begin{array}{l}\text { geometris } \\
\text { dan } \\
\text { geometris, } \\
\text { dengan } \\
\text { ukuran } \\
\text { yang } \\
\text { berbeda } \\
\text { pada } \\
\text { pembuata } \\
\text { nnya serta } \\
\text { perpadua } \\
\text { n antara } \\
\text { motif } \\
\text { geometris } \\
\text { dan non } \\
\text { geometris. }\end{array}$ & $\begin{array}{l}\text { berbentuk } \\
\text { belah } \\
\text { ketupat/waji } \\
\text { k, segitiga, } \\
\text { jajar } \\
\text { genjang, } \\
\text { dan zig-zag. } \\
\text { Ukuran } \\
\text { motif pada } \\
\text { setiap } \\
\text { produk } \\
\text { tenun bulu } \\
\text { cenderung } \\
\text { sama, } \\
\text { memenuhi } \\
\text { seluruh } \\
\text { permukaan } \\
\text { kain }\end{array}$ & $\begin{array}{l}\text { berbentuk } \\
\text { belah } \\
\text { ketupat, } \\
\text { jajar } \\
\text { genjang } \\
\text { dan zig- } \\
\text { zag. } \\
\text { Ukuran } \\
\text { yang } \\
\text { dihasilkan } \\
\text { pada setiap } \\
\text { produk } \\
\text { berbeda- } \\
\text { beda. }\end{array}$ & $\begin{array}{l}\text { non geometris. } \\
\text { Bentuk geometris } \\
\text { yang dihasilkan } \\
\text { disesuaikan } \\
\text { dengan motif non } \\
\text { geometris yang } \\
\text { akan dibuat. }\end{array}$ \\
\hline $\begin{array}{l}\text { Elaboration } \\
\text { (peningkat-an ide, } \\
\text { lebih kompleks) }\end{array}$ & $\begin{array}{l}\text { Mulanya } \\
\text { hanya } \\
\text { membuat } \\
\text { motif non } \\
\text { geometris, } \\
\text { kemudian } \\
\text { mencoba } \\
\text { motif } \\
\text { geometris } \\
\text { lalu } \\
\text { mencoba } \\
\text { memaduk }\end{array}$ & $\begin{array}{l}\text { Motif yang } \\
\text { dibuat } \\
\text { cenderung } \\
\text { lebih sedikit } \\
\text { variannya, } \\
\text { terbatas } \\
\text { hanya pada } \\
\text { motif } \\
\text { geometris, } \\
\text { akan tetapi } \\
\text { ada } \\
\text { perubahan }\end{array}$ & $\begin{array}{l}\text { Motif yang } \\
\text { dibuat } \\
\text { cenderung } \\
\text { lebih sedikit } \\
\text { variannya, } \\
\text { terbatas } \\
\text { hanya pada } \\
\text { motif } \\
\text { geometris, } \\
\text { akan tetapi } \\
\text { ada } \\
\text { perubahan }\end{array}$ & $\begin{array}{l}\text { Motif geometris } \\
\text { yang digunakan } \\
\text { kebanyakan adalah } \\
\text { motif belah } \\
\text { ketupa/wajik, zig- } \\
\text { zag dan diagona, } \\
\text { akan tetapi motif } \\
\text { batik yang } \\
\text { digunakan } \\
\text { cenderung lebih } \\
\text { kompleks. }\end{array}$ \\
\hline
\end{tabular}




\begin{tabular}{|c|c|c|c|c|}
\hline Aspek Kreativitas & $\begin{array}{l}\text { Tenun } \\
\text { Ikat }\end{array}$ & Tenun Bulu & $\begin{array}{l}\text { Tenun } \\
\text { Sulam }\end{array}$ & $\begin{array}{c}\text { Tenun Sulam } \\
\text { Kombinasi Batik }\end{array}$ \\
\hline & $\begin{array}{l}\text { an motif } \\
\text { non } \\
\text { geometris } \\
\text { dan motif } \\
\text { geometris. }\end{array}$ & $\begin{array}{l}\text { pada tekstur } \\
\text { kain. }\end{array}$ & $\begin{array}{l}\text { pada } \\
\text { tekstur } \\
\text { kain. }\end{array}$ & \\
\hline $\begin{array}{l}\text { Originality } \\
\text { (keaslian atau } \\
\text { keunikan produk) }\end{array}$ & $\begin{array}{l}\text { - Merupak } \\
\text { an } \\
\text { produk } \\
\text { pertama } \\
\text { yang di } \\
\text { produksi } \\
\text { kampung } \\
\text { tenun } \\
\text { Panawua } \\
\text { n. } \\
\text { - Motif } \\
\text { yang } \\
\text { dibuat } \\
\text { berdasar } \\
\text { kan } \\
\text { keadaan } \\
\text { sekitar } \\
\text { kampung } \\
\text { Panawua } \\
\text { n dan } \\
\text { an morupak } \\
\text { Garif dari } \\
\text { - Proses }\end{array}$ & $\begin{array}{l}\text { - Merupaka } \\
\text { n produk } \\
\text { kedua } \\
\text { setelah } \\
\text { tenun ikat } \\
\text { yang di } \\
\text { produksi } \\
\text { kampung } \\
\text { tenung } \\
\text { Panawuan } \\
\text {. } \\
\text { - Motif yang } \\
\text { dibuat } \\
\text { seluruhny } \\
\text { a } \\
\text { berbentuk } \\
\text { geometris } \\
\text { dan } \\
\text { cenderung } \\
\text { menutupi } \\
\text { seluruh } \\
\text { permukaa } \\
\text { n kain. } \\
\text { - Warna } \\
\text { yang }\end{array}$ & $\begin{array}{l}\text { - Merupaka } \\
\text { k produk } \\
\text { yanga } \\
\text { diproduksi } \\
\text { di } \\
\text { kampung } \\
\text { tenun } \\
\text { Panawuan } \\
\text { dikarenak } \\
\text { an tenun } \\
\text { ikat dan } \\
\text { tenun bulu } \\
\text { mulai } \\
\text { berkurang } \\
\text { peminatny } \\
\text { a. } \\
\text { - Motif yang } \\
\text { dibuat } \\
\text { seluruhny } \\
\text { a } \\
\text { berbentuk } \\
\text { geometris. } \\
\text { yang }\end{array}$ & $\begin{array}{l}\text { - Merupakan } \\
\text { produk yang di } \\
\text { produksi dengan } \\
\text { menggunakan } \\
\text { teknik sulam dan } \\
\text { batik. } \\
\text { - Motif yang dibuat } \\
\text { berbentuk } \\
\text { geometris dan } \\
\text { non geometris. } \\
\text { - Motif batik yang } \\
\text { digunakan } \\
\text { merupakan motif- } \\
\text { motif yang } \\
\text { menjadi ciri khas } \\
\text { batik } \\
\text { seperti lereng } \\
\text { kangkung, lepaan } \\
\text { bulu hanyam dan } \\
\text { cupat manggu. } \\
\text { - Apabila tenun } \\
\text { dibandingkan } \\
\text { produksi }\end{array}$ \\
\hline
\end{tabular}




\begin{tabular}{|c|c|c|c|c|}
\hline Aspek Kreativitas & $\begin{array}{c}\text { Tenun } \\
\text { Ikat }\end{array}$ & Tenun Bulu & $\begin{array}{l}\text { Tenun } \\
\text { Sulam }\end{array}$ & $\begin{array}{c}\text { Tenun Sulam } \\
\text { Kombinasi Batik }\end{array}$ \\
\hline & $\begin{array}{l}\text { produksi } \\
\text { cenderun } \\
9 \quad \text { lebih } \\
\text { lama. }\end{array}$ & $\begin{array}{l}\text { digunakan } \\
\text { hanya dua } \\
\text { warna, hal } \\
\text { ini } \\
\text { dikarenak } \\
\text { an pada } \\
\text { saat } \\
\text { proses } \\
\text { pertenuna } \\
\text { n, } \\
\text { penambah } \\
\text { an benang } \\
\text { tambahan } \\
\text { dilakukan } \\
\text { bersamaa } \\
\text { n proses } \\
\text { pertenuna } \\
\text { n. } \\
\text { Proses } \\
\text { produksi } \\
\text { lebih } \\
\text { cepat } \\
\text { dibanding } \\
\text { kan tenun } \\
\text { ikat. }\end{array}$ & $\begin{array}{l}\text { digunakan } \\
\text { lebih } \\
\text { banyak } \\
\text { dibanding } \\
\text { kan tenun } \\
\text { sulan, } \\
\text { akan } \\
\text { tetapi } \\
\text { tidak } \\
\text { sebanyak } \\
\text { tenun ikat. } \\
\text { - Proses } \\
\text { produksi } \\
\text { lebih } \\
\text { cepat dari } \\
\text { tenun ikat. }\end{array}$ & $\begin{array}{l}\text { sulam kombinasi } \\
\text { batik memerlukan } \\
\text { waktu produksi } \\
\text { yang lebih lama. }\end{array}$ \\
\hline
\end{tabular}

Data pada Tabel 3.3 merupakan aspek kreativitas dalam kain tenun Panawuan Garut, di mana kreativitas merupakan kemampuan menghasilkan sesuatu yang baru, berupa gagasan maupun karya nyata, baik dalam bentuk karya baru maupun kombinasi dari hal-hal yang sudah ada serta mengandung 
aspek-aspek seperti Fluency Garut disajikan pada Tabel 3.3, tabel (kelancaran), Flexibility (keluwesan), ini menjelaskan seberapa besar aspek Elaboration (elaborasi) dan Originality (keaslian). Matriks antara aspek kreativitas yang terdapat pada kain kreativitas dan kain tenun Panawuan

tenun

Panawuan

Garut.

Tabel 3.4 Matriks antara Aspek Kreativitas dan Produk Tenun

Panawuan Garut

\begin{tabular}{|l|l|l|l|l|}
\hline \multirow{2}{*}{ Aspek kreativitas } & \multicolumn{4}{c|}{ Produk tenun } \\
\cline { 2 - 5 } & Tenun Ikat & $\begin{array}{c}\text { Tenun } \\
\text { Bulu }\end{array}$ & $\begin{array}{c}\text { Tenun } \\
\text { Sulam }\end{array}$ & $\begin{array}{c}\text { Tenun Sulam } \\
\text { Kombinasi Batik }\end{array}$ \\
\hline Fluency (kelancaran) & Baik & Sedang & Kurang & Sangat Baik \\
\hline Flexibility (keluwesan) & Baik & Kurang & Sedang & Sangat Baik \\
\hline Elaboration (elaborasi) & Baik & Kurang & Sedang & Sangat Baik \\
\hline Originality (keaslian) & Sangat Baik & Sedang & Kurang & Baik \\
\hline
\end{tabular}

Tabel 3.4 menjelaskan seberapa besar aspek kreativitas berpengaruh pada kain tenun Panawuan Garut.

- Aspek kreativitas fluency (kelancaran) pada kain tenun ikat Panawuan Garut baik, aspek kreativitas flexibility (keluwesan) pada kain tenun ikat Panawuan Garut baik, aspek kreativitas elaboration (elaborasi) pada kain tenun ikat Panawuan Garut baik, aspek kreativitas originality (keaslian) pada kain tenun ikat Panawuan Garut sangat baik.

- Aspek kreativitas fluency (kelancaran) pada kain tenun bulu
Panawuan Garut sedang, aspek kreativitas flexibility (keluwesan) pada kain tenun bulu Panawuan Garut kurang, aspek kreativitas elaboration (elaborasi) pada kain tenun bulu Panawuan Garut kurang, aspek kreativitas originality (keaslian) pada kain tenun bulu Panawuan Garut sedang.

- Aspek kreativitas fluency (kelancaran) pada kain tenun sulam Panawuan Garut kurang, aspek kreativitas flexibility (keluwesan) pada kain tenun sulam Panawuan Garut sedang, aspek kreativitas elaboration (elaborasi) pada kain 
tenun sulam Panawuan Garut sedang, aspek kreativitas originality (keaslian) pada kain tenun sulam Panawuan Garut kurang.

- Aspek kreativitas fluency (kelancaran) pada kain tenun sulam kombinasi batik Panawuan Garut sangat baik, aspek kreativitas flexibility (keluwesan) pada kain

\section{KESIMPULAN}

Berdasarkan pembahasan

sebelumnya, tujuan dari penelitian ini adalah mendeskripsikan wujud visual motif kain tenun Panawuan Garut ditinjau dari pendekatan estetik serta membuat formulasi kreativitas dalam produk kain tenun Panawuan Garut. Model kajian desain dalam penelitian ini, dipergunakan model kajian estetik dengan metode deskriptif-kualitatif. Data-data yang digunakan dalam penelitian ini merupakan data-data visual pada produk tenun yang dianalisis dengan menggunakan teori estetik morfologi, dimana teori ini berperan dalam mengenali jenis-jenis bentuk, dengan mengenali segi elemen, detail, bagian, material, imaji, ide dan apapun yang termasuk di dalamnya. Sedangkan untuk mendapatkan formulai kreativitas, tenun sulam kombinasi batik Panawuan Garut sangat baik, aspek kreativitas elaboration (elaborasi) pada kain tenun sulam kombinasi batik Panawuan Garut sangat baik, aspek kreativitas originality (keaslian) pada kain tenun sulam kombinasi batik Panawuan Garut baik.

wujud visual dari produk tenun terutama motif yang dihasilkan dikorelasikan dengan prinsip kreativitas. Maka hasil analisis tersebut dapat disimpulkan sebagai berikut:

1. Pemaparan mengenai wujud motif kain tenun Panawuan Garut ditinjau dari pendekatan estetik:

- Tenun Ikat Panawuan Garut Motif tenun ikat yang ada di Panawuan Garut umumnya merupakan motif geometris dan non geometris yang terinspirasi keadaan sekitar kampung Panawuan Garut. Bentuk geometrisnya umumnya adalah garis miring dan belah ketupat, sedangkan bentuk non geometrisnya adalah gambaran alam, flora dan fauna. Layout tenun ikat yaitu satu bata, dengan elemen yang terdapat pada tenun ini adalah garis lengkung dan garis lurus. 
Tekstur dari tenun ikat ini adalah tenun dengan anyaman polos. Ciri tenun ikat Panawuan Garut umumnya dapat dilihat dari penggunaan warnanya yang cenderung kalem dan tidak mencolok. Dasar warnanya biasanya biru tua dan coraknya menggunakan warna seperti kuning, merah, putih, coklat, dan hijau. Pada motif tenun ikat umumnya tidak mengandung simbol yang dikaitkan dengan simbol tertentu, tetapi lebih bersifat kreasi pengrajin tenun dalam mengekspresikan bentuk dan keadaan alam sekitarnya.

- Tenun Bulu Panawuan Garut

Tenun bulu Panawuan Garut memiliki ciri khas motif geometris, bentuk geometrisnya di antaranya adalah garis miring, zig zag dan belah ketupat. Layout tenun bulu motif wajik yaitu satu bata, elemen yang terdapat pada tenun ini adalah garis lurus. Tekstur dari tenun ini adalah tenun dengan benang tambahan yang digunting sehingga menghasilkan bulu-bulu halus pada permukaan kain, sedangkan warna yang digunakan terdiri dari 2 warna. Ciri tenun bulu Panawuan Garut umumnya dapat dilihat dari penggunaan warnanya yang cenderung kalem dan tidak mencolok. Dasar warnanya biasanya putih dan coraknya menggunakan warna seperti orange, merah, putih, coklat, biru dan krem. Warna yang digunakan dalam pembuatan tenun bulu terdiri dari maksimal tiga warna hal ini dikarenakan faktor produksi, dimana pada proses pembuatannya benang yang digunakan selalu berkesinambungan, tidak bisa diganti-ganti seperti pada proses pembuatan tenun sulam. Pada motif tenun bulu umumnya tidak mengandung simbol yang dikaitkan dengan simbol tertentu, tetapi lebih bersifat kreasi pengrajin tenun dalam mengekspresikan bentuk dan keadaan alam sekitarnya.

- Tenun Sulam Panawuan Garut Motif tenun sulam merupakan motif geometris yang merupakan kombinasi dari garis diagonal, zig-zag atau belah ketupat/wajik. Layout tenun sulam yaitu satu 
bata, elemen yang terdapat pada tenun ini adalah garis lurus. Tekstur dari tenun sulam ini adalah tenun dengan benang tambahan, sedangkan warna yang digunakan bisa lebih dari 2 warna, berbeda dengan pembuatan tenun bulu yang ratarata hanya menggunakan 2 warna dalam proses pembuatannya, hal ini dikarenakan adanya teknik produksi yang berbeda dalam pembuatan tenun sulam dan tenun bulu. Ciri tenun sulam Panawuan umumnya dapat dilihat dari penggunaan warnanya yang cenderung kalem dan tidak mencolok. Warna yang digunakan biasanya biru tua, abu-abu, hitam, merah, kuning. Pada motif tenun sulam umumnya tidak mengandung simbol yang dikaitkan dengan simbol tertentu, tetapi lebih bersifat kreasi pengrajin tenun dalam mengekspresikan bentuk dan keadaan alam sekitarnya.

- Tenun Sulam Kombinasi Batik Panawuan Garut.

Motif tenun ini merupakan kombinasi motif geometris dan non geometris. Bentuk geometrisnya umumnya adalah garis miring, zig zag dan belah ketupat, sedangkan bentuk non geometrisnya adalah gambaran alam, flora dan fauna yang bersifat tergantung kreasi pengrajin tenun dalam mengekspresikan bentuk dan keadaan alam sekitarnya. Layout motif pada tenun ini adalah satu bata, dimana elemen yang terdapat pada tenun ini adalah titik, garis lurus dan garis lengkung. Tekstur dari tenun sulam kombinasi batik ini adalah tenun dengan benang tambahan yang kemudian diberi proses tambahan yaitu proses pembuatan batik. Motif batik yang digunakan diantaranya motif sekar jagad, lereng kangkung, cupat manggu, lepaan bulu hayam dan kawung. Warna cerah tetapi tidak menonjol menjadi ciri khas batik Garutan. Warna-warna tersebut didominasi oleh warna dasar krem atau gading (gumading), biru dan soga. Warna dasar yang mencerminkan alam itu dihadirkan pula dengan corak atau motif yang dekat 
dengan kehidupan masyarakat. Pengelompokannya dalam bentuk geometris dan non geometris.

Motif kain tenun Panawuan Garut dianalisis menggunakan estetik morfologi, di mana yang diteliti adalah bentuk yang dihasilkan pada kain tenun Panawuan Garut. Adapun bentuk yang paling dominan terdapat pada kain tenun Panawuan Garut adalah bentuk miring wajik dan zig-zag, hal ini dikarenakan pada saat proses produksi bentuk tersebut lebih mudah diaplikasikan pada produk tenun. Elemen utama pembentuk motif kain tenun Panawuan Garut yaitu garis lurus dan garis lengkung. Tekstur yang ada pada kain tenun Panawuan Garut dihasilkan melalui suatu proses desain tekstil yaitu desain permukaan di mana desain terbentuk setelah kain selesai ditenun. Warnawarna yang cenderung digunakan pada kain tenun Panawuan Garut umumnya tidak mencolok diantaranya warna merah, biru, coklat, kuning, hijau dan putih.
2. Pemaparan mengenai wujud visual yang terdapat pada produk tenun berkorelasi dengan prinsip kreativitas.

Analisis dalam penelitian mengarah pada motif kain tenun Panawuan Garut. Wujud visual yang terdapat pada produk tenun Panawuan dianalisis melalui pendekatan morfologi estetik yang kemudian wujud kreativitasnya di bedah dengan menggunakan prinsipprinsip kreativitas yang ada di tenun Panawuan. Kreativitas dalam produk tenun Panawuan memiliki 4 aspek yang utama yaitu fluency (kelancaran), kelancaran mengacu pada sebuah ide untuk memecahkan suatu masalah, dalam hal ini dimana ide-ide pembuatan kain selain tenun ikat sudah dilaksanakan oleh perajin sehingga adanya variasi produk yang dihasilkan; flexibility (keluwesan), keluwesan mengacu pada proses peningkatan gagasan dengan membuatnya menjadi lebih detail, membuat produk lain selain tenun ikat seperti proses pembuatan tenun sulam, tenun bulu dan tenun sulam kombinasi batik; elaboration (elaborasi), mengacu pada proses 


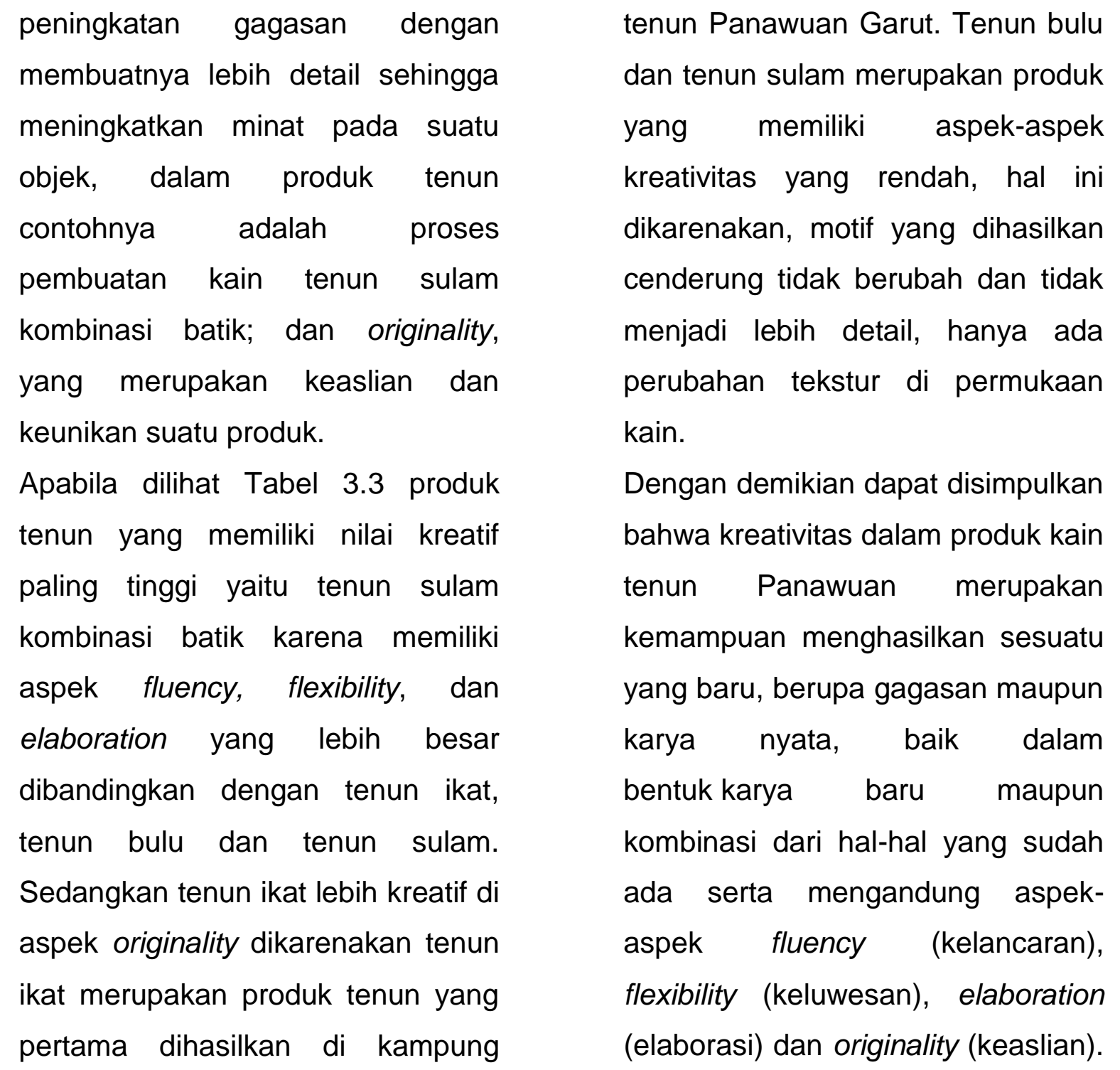




\section{DAFTAR PUSTAKA}

1. Akbar, Reni Hawadi. (2001). Psikologi dan Perkembangan Anak (Mengenal sifat, bakat dan kemampuan anak). Jakarta: PT. Gramedia

2. Bukhori Z. Imam. (1989). Peranan Estetik Dalam Desain. Bandung: Institut Teknologi Bandung (ITB)

3. Darmaprawira W.A, Sulasmi. (2002). Warna: Teori dan Kreativitas Penggunaannya. Bandung: Penerbit ITB.

4. Djelantik, A.A.M., (1999). ESTETIKA Sebuah Pengantar, Masyarakat Seni Pertunjukkan Indonesia, Bandung.

5. Jumaeri, dkk. (1974). Textile Design, Institut Teknologi Tekstil.

6. Kartiwa, Suwati. (1989). Ragam Kain Tradisional Indonesia Tenun Ikat. Jakarta: Djambatan.

7. Kartiwa, S., (2007). Tenun Ikat, Ragam Kain Tradisional Indonesia. Jakarta: PT Gramedia Pustaka Utama.

8. Lawson, Bryan, (1983). How Desainer Think, London: Architectural Press.

9. Munandar, U., (2009). Pengembangan Kreativitas Anak Berbakat. Jakarta: Rineka Cipta.

10. Munro, Thomas, (1970). Form and Style in The Arts: An Introduction to Aesthetic Morphology. Cleveland and London: The Press of Case Western Reserve University/The Cleveland Museum of Art.

11. Ngalimun, dkk., (2013). Perkembangan dan Pengembangan Kreativitas. Yogyakarta: Aswaja Pressindo

12. Rhodes, M., (1961). An Analysis Of Creativity. The Phi Delta Kappan, 42(7), 305310.

13. Semiawan. Conny R., (2009). Kreativitas dan Keberbakatan Jakarta: PT. Indeks.

15. Stenberg, R. J., Kaufman J.C., \& Prez J.E. (2002). The Creativity. New York: Psychology Press.

16. Sugiyono. (2005). Memahami Penelitian Kualitatif, Bandung.

17. Sunarsono, H., dkk., (2016). Batik Garutan: Koleksi Hartono Sumarsono, PT. Gramedia Jakarta.

18. Sunarya, Y. (2013). Batik: Digitalisasi Kreatif Motif dalam Gaya Desain Dunia, Bandung: LP4 ITB dan Penerbit ITB. 